\title{
Oleanolic acid induces mitochondrial-dependent apoptosis and G0/GI phase arrest in gallbladder cancer cells
}

This article was published in the following Dove Press journal:

Drug Design, Development and Therapy

12 June 2015

Number of times this article has been viewed

\author{
Huai-Feng Li, ${ }^{\mathrm{I}-3, *}$ Xu-An \\ Wang, ${ }^{1-3, *}$ Shan-Shan \\ Xiang, ${ }^{1-3, *}$ Yun-Ping $\mathrm{Hu},{ }^{1-3}$ \\ Lin Jiang, ${ }^{1-3}$ Yi-Jun Shu, ${ }^{1-3}$ \\ Mao-Lan Li, ${ }^{1-3}$ Xiang-Song \\ Wu, ${ }^{1-3}$ Fei Zhang, ${ }^{1-3}$ Yuan- \\ Yuan Ye, ${ }^{1-3}$ Hao Weng, ${ }^{1-3}$ \\ Run-Fa Bao, ${ }^{1-3}$ Yang Cao, ${ }^{1-3}$ \\ Wei Lu, ${ }^{1-3}$ Qian Dong, ${ }^{1-3}$ \\ Ying-Bin Liu ${ }^{1-3}$ \\ 'Department of General Surgery, \\ ${ }^{2}$ Laboratory of General Surgery, \\ ${ }^{3}$ Institute of Biliary Tract Disease, \\ Xinhua Hospital, Affiliated to Shanghai \\ Jiao Tong University, School of \\ Medicine, Shanghai, People's Republic \\ of China \\ *These authors contributed equally \\ to this work
}

\begin{abstract}
Oleanolic acid (OA), a naturally occurring triterpenoid, exhibits potential antitumor activity in many tumor cell lines. Gallbladder carcinoma is the most common malignancy of the biliary tract, and is a highly aggressive tumor with an extremely poor prognosis. Unfortunately, the effects of OA on gallbladder carcinoma are unknown. In this study, we investigated the effects of OA on gallbladder cancer cells and the underlying mechanism. The results showed that OA inhibits proliferation of gallbladder cancer cells in a dose-dependent and time-dependent manner on MTT and colony formation assay. A flow cytometry assay revealed apoptosis and G0/G1 phase arrest in GBC-SD and NOZ cells. Western blot analysis and a mitochondrial membrane potential assay demonstrated that OA functions through the mitochondrial apoptosis pathway. Moreover, this drug inhibited tumor growth in nude mice carrying subcutaneous NOZ tumor xenografts. These data suggest that OA inhibits proliferation of gallbladder cancer cells by regulating apoptosis and the cell cycle process. Thus, OA may be a promising drug for adjuvant chemotherapy in gallbladder carcinoma.
\end{abstract}

Keywords: oleanolic acid, gallbladder carcinoma, apoptosis, cell cycle arrest, mitochondrial pathway

\section{Introduction}

Carcinoma of the gallbladder, although generally considered rare, is the most common malignancy of the biliary tract and the sixth most common cancer of the gastrointestinal system, albeit showing striking geographic and ethnic disparities. Gallbladder carcinoma is a highly aggressive and lethal neoplasm with a high mortality and an extremely poor prognosis. ${ }^{1-9}$ Because of the vague symptoms and signs, it is usually detected at an advanced stage. Surgical resection is the only potentially curative therapy for gallbladder carcinoma; however, the majority of patients suffer recurrences after surgery. For patients with unresectable and recurrent disease, chemotherapy or radiotherapy will be the only way to choose, unfortunately, the outcomes are unsatisfactory. As a result, gallbladder carcinoma is associated with a very poor prognosis, and the mean overall survival rate for this malignancy is a mere 6 months and the 5-year survival rate is only 5\%, which closely follow incidence..$^{2,10-13}$ Therefore, novel effective therapeutic drugs are urgently needed for this deadly disease.

Oleanolic acid (OA), a naturally occurring triterpenoid (Figure 1), is widely distributed in food and medicinal plants, and is related to betulinic acid. It can be found in olive oil, Olea europaea L, Ligustrum lucidum ait, Phytolacca Americana (American pokeweed), Syzygium spp, and garlic. It is relatively nontoxic, is hepatoprotective, 


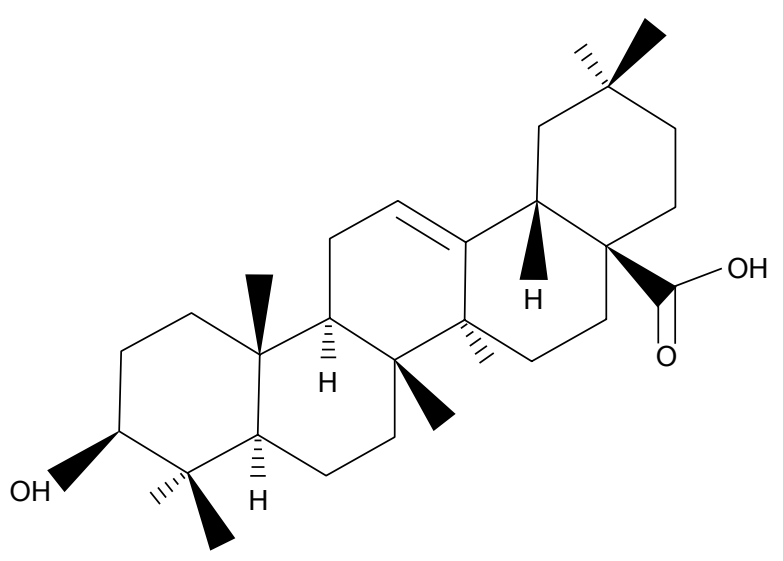

Figure I Chemical structure of oleanolic acid.

and has antitumor and antiviral properties. OA has been shown to have antineoplastic activity, with previous studies reporting that OA can suppress proliferation of lung carcinoma cells via the miR-122/cyclin G1/MEF2D axis, inhibit hepatocellular carcinoma via ERK-p53-mediated cell cycle arrest and mitochondrial-dependent apoptosis, and inhibit proliferation and invasiveness of Kras-transformed cells via autophagy. ${ }^{14-19}$ However, the effect of OA on gallbladder cancer cells and the potential mechanism involved have not been reported. In this study, we investigated the antineoplastic activity of OA in gallbladder cancer (GBC-SD and NOZ) cell lines in vitro and in vivo, and explored the possible molecular mechanisms involved. This study could provide experimental evidence for applying $\mathrm{OA}$ as a new natural antitumor medicine for gallbladder carcinoma.

\section{Materials and methods}

\section{Chemicals and reagents}

OA was purchased from Sigma-Aldrich (St Louis, MO, USA). For the in vitro studies, OA was dissolved in dimethyl sulfoxide (DMSO) to create a stock solution $(0.1 \mathrm{M})$ which was stored at $-20^{\circ} \mathrm{C}$. For working solutions, the stock solution was further diluted with culture medium to yield the desired concentration. Control cells were treated with an equal volume of vehicle. The DMSO concentration was kept below $0.1 \%$ in cell culture and no detectable effect on cell growth or cell death were observed.

3-[4,5-dimethylthiazol-2-yl]-2,5-diphenyl-tetrazolium bromide (MTT), Annexin V-fluorescein isothiocyanate (FITC), propidium iodide (PI), Hoechst 33342, and Rhodamine 123 were purchased from Sigma Chemical Company (St Louis, MO, USA). Primary and secondary antibodies (goat antirabbit) were purchased from Cell Signaling Technology (Danvers, MA, USA).

\section{Cell lines and culture}

GBC-SD and NOZ (human gallbladder cancer) cell lines were purchased from the Shanghai Institute of Cell Biology, Chinese Academy of Sciences (Shanghai, People's Republic of China) and cultured in high-glucose Dulbecco's Modified Eagle's Medium (Gibco, Grand Island, NY, USA). The medium was supplemented with $10 \%$ fetal bovine serum (Gibco) and $100 \mu \mathrm{g} / \mathrm{mL}$ streptomycin and $100 \mathrm{U} / \mathrm{mL}$ penicillin (Hyclone, Logan, UT, USA), and maintained at $37^{\circ} \mathrm{C}$ in a humidified atmosphere with $5 \% \mathrm{CO}_{2}$.

\section{Cell viability assay}

Cell viability was measured using the MTT assay. GBC-SD and NOZ cells $\left(5 \times 10^{3} /\right.$ well $)$ were seeded into 96 -well plates, incubated overnight, and treated with $\mathrm{OA}$ at final concentrations of $0,30,50,70$, and $90 \mu \mathrm{mol} / \mathrm{L}$ for 24,48 , and 72 hours. After treatment, $20 \mu \mathrm{L}$ of MTT solution $(5 \mathrm{mg} / \mathrm{mL})$ was added to each well and the cells were incubated at $37^{\circ} \mathrm{C}$ for 4 hours. The culture medium were then replaced with $100 \mu \mathrm{L}$ of DMSO. Absorbance of the solution at $490 \mathrm{~nm}$ was measured with a microplate reader (Bio-Tek, Winooski, VT, USA). The results represent the average of five parallel samples.

\section{Colony formation assay}

GBC-SD and NOZ cells in the logarithmic growth phase were liquated as single cell suspensions and 500 cells were placed into each well of six-well plates (Corning, Corning, NY, USA). After adherence, cells were treated with OA ( 0 , 3,6 and $9 \mu \mathrm{mol} / \mathrm{L}$ for GBC-SD and NOZ) for 48 hours. The OA-containing medium was then removed, and the cells were allowed to form colonies in complete medium for 14 days. The cells were then fixed with $4 \%$ paraformaldehyde for 15 minutes and stained with $0.1 \%$ crystal violet (Sigma-Aldrich) for 30 minutes. After washing, the plates were air-dried, and the stained colonies were photographed using a microscope (Leica, Wetzlar, Germany). The total number of colonies ( $>50$ cells/colony) was counted manually.

\section{Cell apoptosis assay}

Cells were seeded in six-well plates and treated with OA $(0$, 30,60 , and $90 \mu \mathrm{mol} / \mathrm{L}$ ) for 48 hours. Adherent cells were then harvested by trypsinization, and floating cells were also harvested. After washing twice with cold phosphate-buffered saline (PBS), the cells were resuspended at a density of $1 \times 10^{6}$ cells $/ \mathrm{mL}$. Next, $100 \mu \mathrm{L}$ of binding buffer containing $5 \mu \mathrm{L}$ of Annexin V-FITC and $5 \mu \mathrm{L}$ of PI working solution $(100 \mu \mathrm{g} / \mathrm{mL})$ was added to the cells, followed by incubation 
in the dark for 30 minutes, after which $400 \mu \mathrm{L}$ of binding buffer was added to suspension. The samples were then immediately analyzed by flow cytometry (BD Biosciences, San Diego, CA, USA).

\section{Cell cycle analysis}

GBC-SD and NOZ cells were treated with different concentrations of OA $(0,30,60$, and $90 \mu \mathrm{mol} / \mathrm{L})$ for 48 hours. Cells (floating and adherent) were then harvested, washed twice in cold PBS, and fixed in $70 \%$ ethanol at $4^{\circ} \mathrm{C}$ overnight. After fixation, the cells were washed and resuspended in cold PBS and incubated in a solution of $10 \mathrm{mg} / \mathrm{mL}$ RNase and $1 \mathrm{mg} / \mathrm{mL}$ PI (Sigma-Aldrich) at $37^{\circ} \mathrm{C}$ in the dark for 30 minutes. Finally, the samples were analyzed by flow cytometry (BD Biosciences). The percentages of cells in the G0/G1, S, and G2/M phases were determined using Cell Quest acquisition software (BD Biosciences).

\section{Mitochondrial membrane potential assay}

Rhodamine 123 was used to determine the mitochondrial membrane potential $(\Delta \Psi \mathrm{m})$. After treatment with different concentrations of $\mathrm{OA}(0,30,60$, and $90 \mu \mathrm{mol} / \mathrm{L})$ for 48 hours, GBC-SD and NOZ cells (floating and adherent) were harvested and washed twice with cold PBS. The cells were then incubated with Rhodamine 123 (Sigma-Aldrich) for 30 minutes at $37^{\circ} \mathrm{C}$ with $5 \% \mathrm{CO}_{2}$ in the dark. The cells were then washed twice with cold PBS and analyzed by flow cytometry (BD Biosciences).

\section{Observation of morphological changes with Hoechst 33342 staining}

After treatment with $\mathrm{OA}(0,30,60$, and $90 \mu \mathrm{mol} / \mathrm{L})$ for 48 hours, the GBC-SD and NOZ cells were washed twice in cold PBS and fixed with methanol:acetic acid (ratio 3:1) at room temperature for 15 minutes. The cells were then washed in PBS and stained with Hoechst $333425 \mu \mathrm{g} / \mathrm{mL}$ for 10 minutes at $37^{\circ} \mathrm{C}$. Finally, the cells were washed with PBS and observed under a fluorescence microscope (Leica).

\section{Western blot analysis}

Cells were treated with OA $(0,30,60$ and $90 \mu \mathrm{mol} / \mathrm{L})$ for 48 hours, after which both adherent and floating cells were harvested, washed twice with cold PBS, and lysed in RIPA buffer (Beyotime Institute of Biotechnology, Beijing, People's Republic of China) and protease inhibitor (Roche Applied Science, Indianapolis, IN, USA) at $4^{\circ} \mathrm{C}$ for 5 minutes. After centrifugation at $14,000 \times g$ for 5 minutes, the supernatant was extracted, and the protein concentration of the cell extracts was determined using a bicinchoninic acid assay kit (Beyotime Institute of Biotechnology) according to the manufacturer's instructions. Equal amounts of protein lysate (40 $\mu \mathrm{g} / \mathrm{lane})$ from each sample were separated by $10 \%$ sodium dodecyl sulfate polyacrylamide gel electrophoresis and then electrophoretically transferred to nitrocellulose membranes (Millipore, Bedford, MA, USA). Each membrane was blocked with 5\% skim milk, and then incubated with the indicated primary antibodies against Bcl-2, Bax, cleaved caspase-3, cleaved caspase-9, cleaved PARP, cytochrome C, cyclin D1, CDK4, and glyceraldehyde-3-phosphate dehydrogenase $(1: 1,000)$ at $4^{\circ} \mathrm{C}$ overnight. After washing with TBST buffer, the membrane was incubated with secondary antibodies (horseradish peroxidase-conjugated goat antirabbit immunoglobulin $\mathrm{G}$, 1:5,000; Abcam, Cambridge, UK) for 1 hour at room temperature. The bands were visualized using Gel Doc 2000 (Bio-Rad, Hercules, CA, USA).

\section{Experimental animals}

Male athymic nude mice (aged 4-6 weeks initial body weight $20 \pm 2 \mathrm{~g}$ ) were purchased from Shanghai SLAC Laboratory Animal Co Ltd. (Shanghai, People's Republic of China). The animals were housed at a temperature of $25^{\circ} \mathrm{C} \pm 2{ }^{\circ} \mathrm{C}$ and a relative humidity of $70 \% \pm 5 \%$ under natural light/dark conditions for 1 week and allowed free access to food and water. The animal experiments were performed in strict accordance with international ethical guidelines and the National Institutes of Health Guide for the Care and Use of Laboratory Animals (SYXK [Shanghai] 2013-0106). The protocols were approved by the Institutional Animal Care and Use Committee of Shanghai Jiao Tong University.

\section{In vivo tumor xenograft study}

NOZ cells in log-phase growth were resuspended in serum-free culture medium (at a density of $1 \times 10^{6}$ cells in $0.2 \mathrm{~mL}$ ). Tumor xenografts were then established by subcutaneous inoculation of these NOZ cells into the right flank of each nude mouse. Twenty-four hours after inoculation, the mice were randomly divided into three groups (ten mice per group). One group was administered vehicle (10\% DMSO and 90\% PBS) intraperitoneally and the others were administered OA (75 or $150 \mathrm{mg} / \mathrm{kg}$ intraperitoneally) as described by Wang et $\mathrm{al}^{17}$ in a volume of $0.2 \mathrm{~mL}$ every 2 days for up to 15 days. On day 16, the animals were euthanized, and the tumor tissues were removed and weighed. 


\section{Immunohistochemistry and hematoxylin- eosin staining}

Tumors from the nude mice treated with OA were formalinfixed and paraffin-embedded, and histological sections of $5 \mathrm{~mm}$ were taken from each group of tumor tissues. Expression patterns for Ki-67 were analyzed via immunohistochemical streptavidin-peroxidase staining. The working concentration of primary antibody against Ki-67 used was 1:100 (rabbit polyclonal antibody, Abcam). The empirical procedure for immunohistochemistry and hematoxylin-eosin staining was performed according to the manufacturers' instructions. The scoring of the Ki-67 immunohistochemistry staining was performed as follows: the degree of staining is divided into three levels according to shade of color, ie, yellow (1 point), light brown ( 2 points), and dark brown (3 points); the percentage of area staining positive is also divided into three levels, ie, $<25 \%$ ( 1 point), $25 \%-50 \%$ ( 2 points), and $>50 \%$ ( 3 points). The final score of each group is the product of the two scoring and the mean of ten high power fields which were chosen randomly.

\section{Statistical analysis}

All experiments were performed at least three times, and values are expressed as the mean \pm standard deviation unless otherwise stated. The Student's $t$-test was used to compare the difference between treated groups and their controls. $P<0.05$ was considered to be statistically significant.

\section{Results}

\section{OA inhibits proliferation and viability of gallbladder cancer cells}

The MTT assay were carried out to test cell proliferation. Treatment with OA resulted in a marked decrease in viability of GBC-SD and NOZ cells in a dose-dependent and timedependent manner (Figure 2A). The half maximal inhibitory concentration $\left(\mathrm{IC}_{50}\right)$ of the $\mathrm{GBC}-\mathrm{SD}$ and $\mathrm{NOZ}$ cells at 48 hours was approximately $50 \mu \mathrm{mol} / \mathrm{L}$. According to the curve, we chose 30,60 , and $90 \mu \mathrm{mol} / \mathrm{L}$ as the optimum concentration range for both cell lines in the subsequent experiments, and the effects of OA at 48 hours were more obvious and stable than at 24 hours and 72 hours, so groups at 48 hours were chosen to detect changes in molecular events during the subsequent experiments. The ability of GBC-SD and $\mathrm{NOZ}$ cells to form colonies in the presence of OA was assessed by the flat plate colony formation assay (Figure 2B). The colony count indicated that $\mathrm{OA}$ induced a dosedependent decrease in colony formation ability. Moreover, statistical analysis demonstrated that the mean sizes of the control colonies were significantly larger than those of the OA-treated groups (Figure 2C). These findings demonstrate that $\mathrm{OA}$ significantly inhibits the viability and proliferation of GBC-SD and NOZ cells.

\section{OA induces mitochondrial-dependent apoptosis in gallbladder cancer cells}

The apoptotic effects of OA on GBC-SD and NOZ cells were investigated by measuring the binding of Annexin V-FITC/ PI staining. As assessed by flow cytometry and shown in Figure 3A, OA reduced the number of surviving cells and increased the number of both early and late apoptotic cells in a dose-dependent manner (Figure 3B).

Apoptosis was also confirmed by examining nuclear morphology by Hoechst 33342 staining. The cells in the control group were round and homogeneously stained, whereas OA-treated cells showed obvious chromatin condensation and fragmentation (Figure 3C). Moreover, the numbers of apoptotic nuclei containing condensed chromatin increased significantly as the OA concentration increased. Based on these morphological changes, OA seems to cause apoptosis of gallbladder cancer cells.

The mitochondria play an important role in the regulation of apoptosis, and apoptosis mediated by the mitochondrial pathway is often associated with a decrease in the $\Delta \Psi \mathrm{m}$. The $\Delta \Psi \mathrm{m}$ changes in GBC-SD and NOZ cells were tested by staining with Rhodamine 123 after 48 hours of treatment of $\mathrm{OA}$, and the staining was detected by flow cytometry. ${ }^{20}$ The decrease in intensity of Rhodamine 123 fluorescent staining reflected loss of the $\Delta \Psi \mathrm{m}$. As is shown in Figure $4 \mathrm{~A}$ and $\mathrm{B}$, a dose-dependent reduction in $\Delta \Psi \mathrm{m}$ was observed in OAtreated cells.

It is well known that proteins in the Bcl-2 family and caspase family, along with cytochrome $\mathrm{C}$ and PARP, play critical roles in the mitochondrial apoptotic process. ${ }^{21-23}$ To further investigate the underlying molecular mechanism of OA-induced apoptosis in GBC-SD and NOZ cells, expression of apoptosis-related proteins were evaluated by Western blot analysis after treating the cells with various concentrations of OA for 48 hours. As shown in Figure 5A, upregulation of Bax, cytochrome $\mathrm{C}$, cleaved caspase-9, cleaved caspase-3, and cleaved PARP and downregulation of Bcl-2 were induced by $\mathrm{OA}$ in a dose-dependent manner. The ratio of Bcl-2 to Bax determines the occurrence and severity of apoptosis during apoptotic stimuli. An increased ratio of Bcl-2 to Bax promotes cell survival; whereas a decreased ratio of Bcl-2 to Bax promotes cell apoptosis. ${ }^{24}$ From our Western blot assay, we found that the ratio of Bcl-2 to Bax 
A

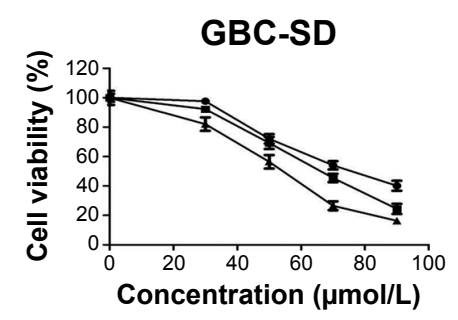

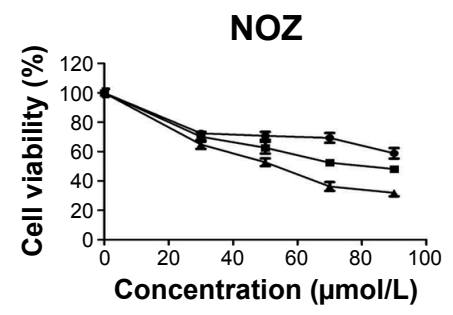

Concentration $(\mu \mathrm{mol} / \mathrm{L})$

B

$\rightarrow 24$ hours $\rightarrow-48$ hours $\rightarrow 72$ hours

\section{Concentration ( $\mu \mathrm{mol} / \mathrm{L})$}

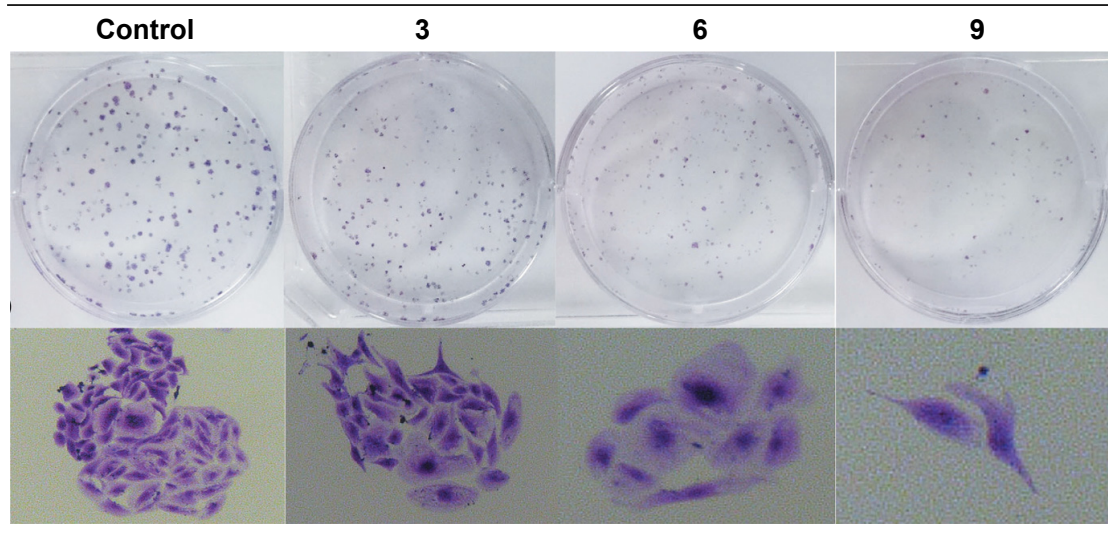

GBC-SD
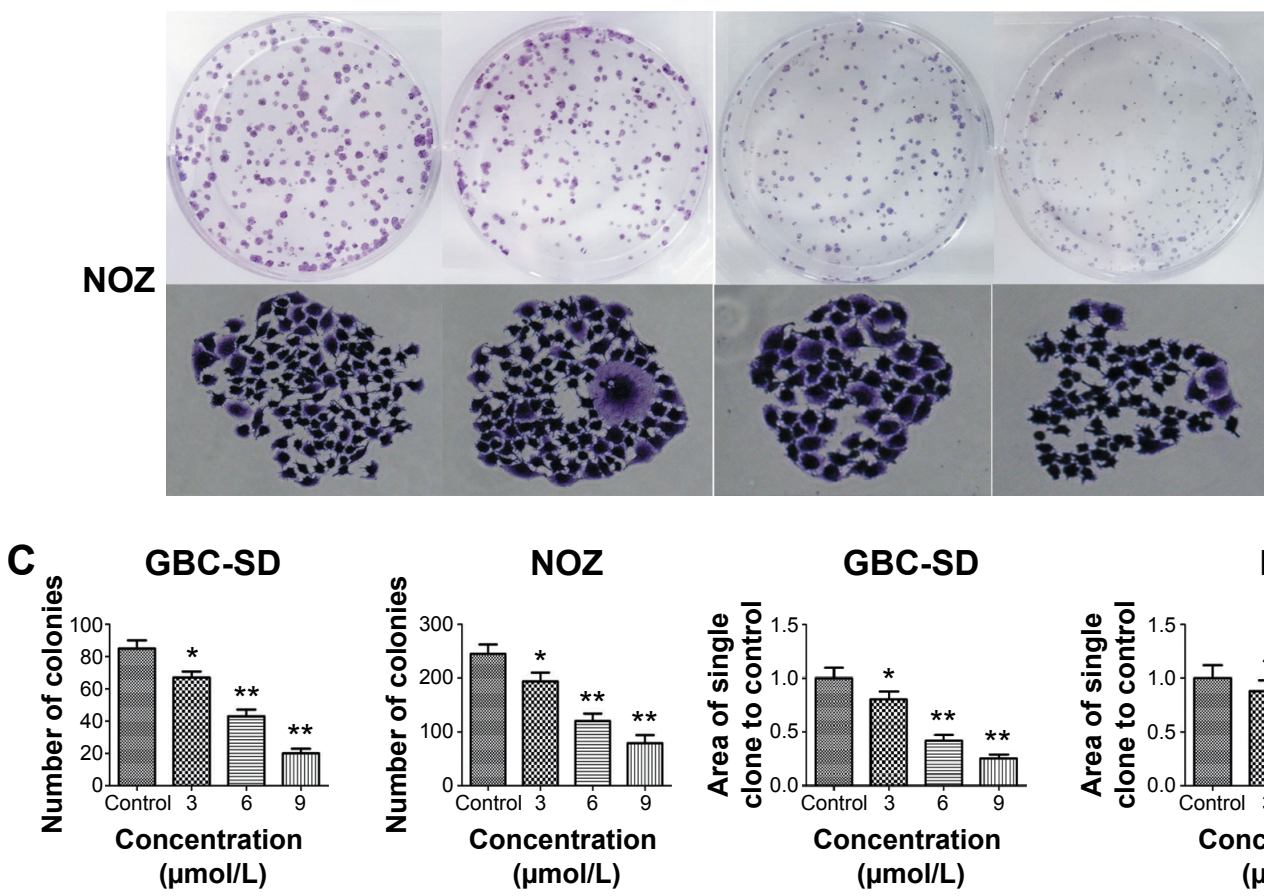

GBC-SD

NOZ
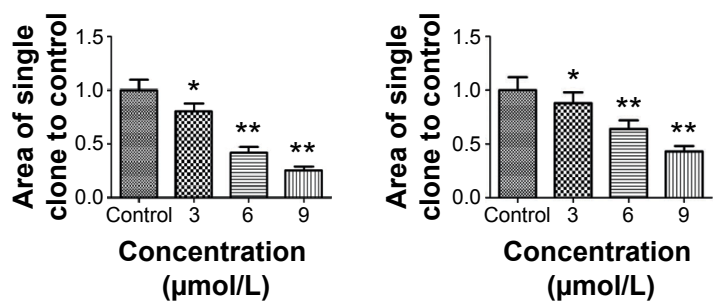

Figure 2 Oleanolic acid inhibits proliferation and viability of gallbladder cancer cells.

Notes: (A) Cell viability and IC 50 were measured by MTT assay. (B) GBC-SD and NOZ cells were treated with various concentrations of oleanolic acid ( $0,3,6$, and $9 \mu$ mol/L) for 48 hours and then allowed to form colonies in fresh medium without oleanolic acid for 14 days. (C) Detailed information on colony formation is shown. All data are presented as the mean \pm standard deviation and are from three independent experiments. $* P<0.05, * * P<0.0$ I versus the control group.

decreased sharply after adding OA to the gallbladder cancer cells in a dose-dependent manner (Figure 5B).

Taken together, OA promotes apoptosis of gallbladder cancer cells through the mitochondrial-dependent apoptotic pathway.

\section{OA induces G0/GI phase arrest by} regulating expression of cell cycle-related proteins in gallbladder cancer cells

Cell cycle distribution was analyzed using flow cytometry after treatment with OA for 48 hours. The results show that 


\section{A}

OA ( $\mu \mathrm{mol} / \mathrm{L})$
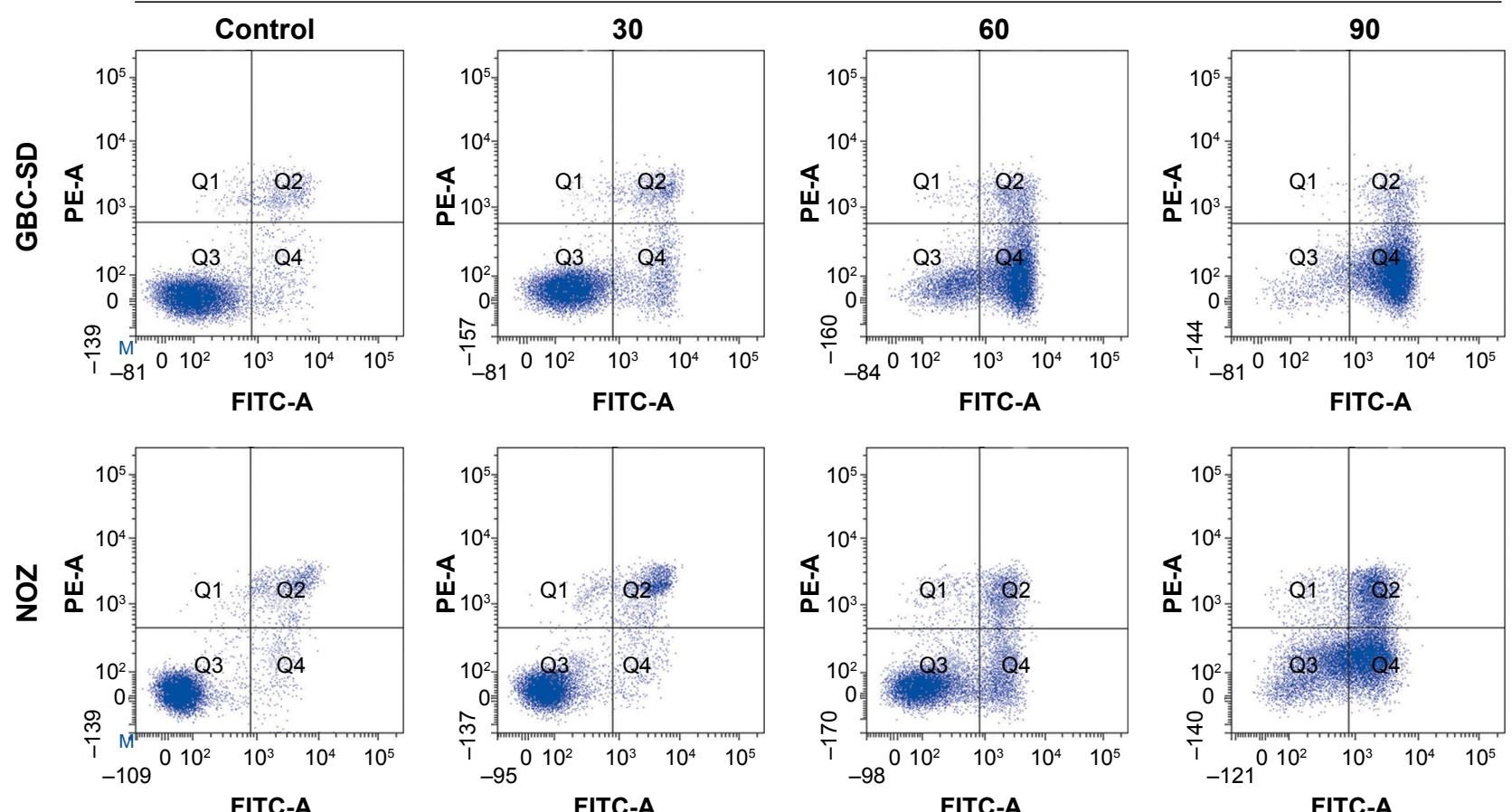

B

GBC-SD

NOZ
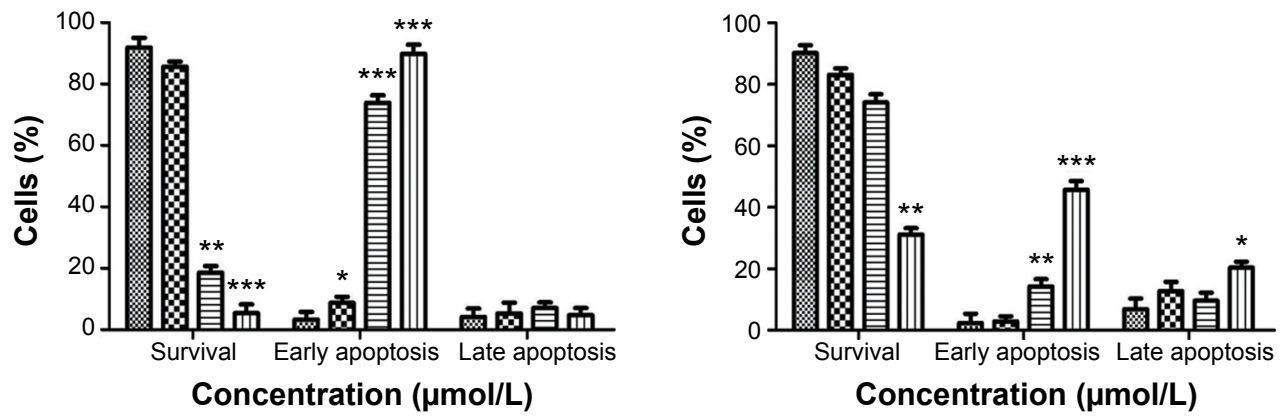

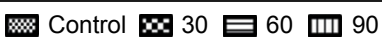

C

Concentration $(\mu \mathrm{mol} / \mathrm{L})$

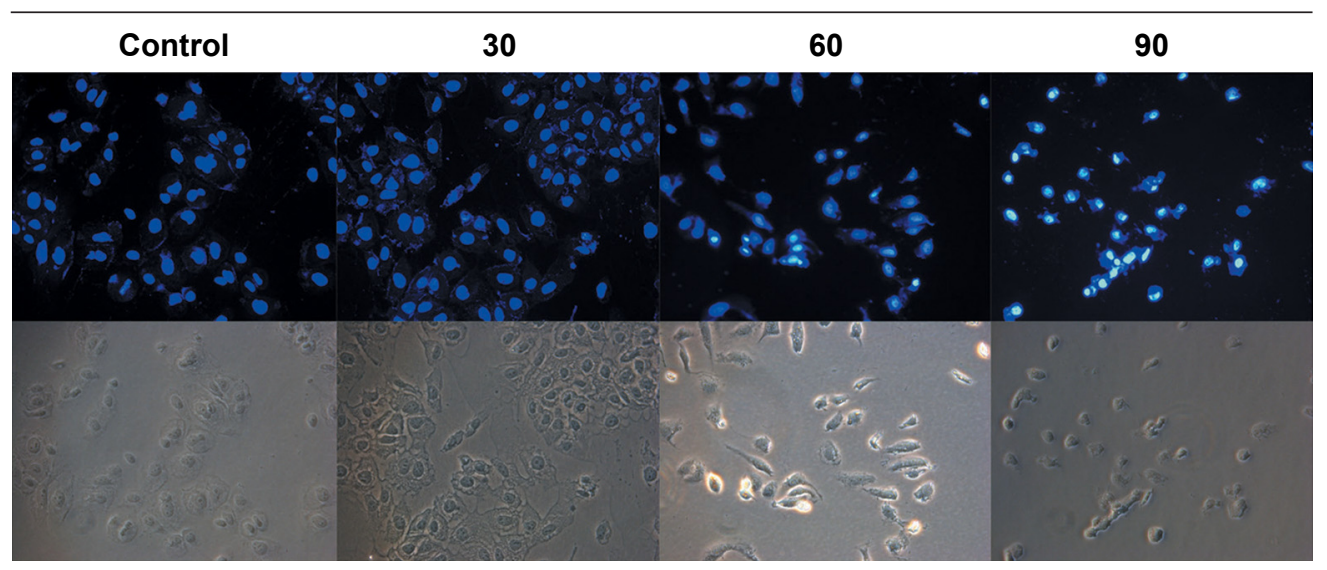

Figure 3 (Continued) 


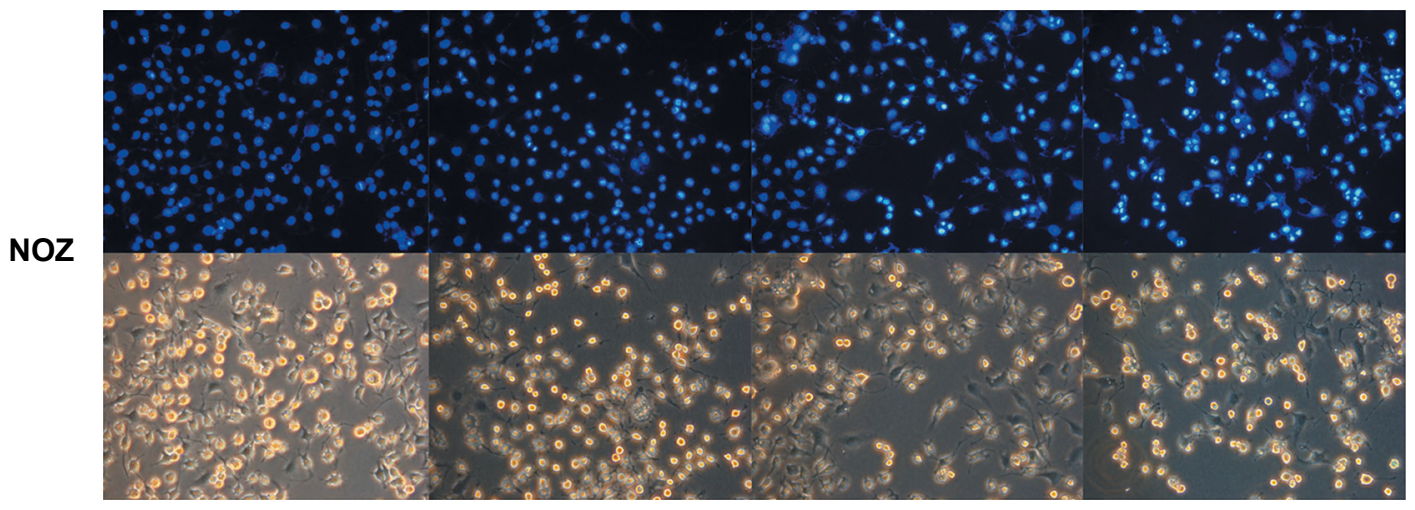

Figure 3 Oleanolic acid induces apoptosis in gallbladder cancer cells.

Notes: (A) GBC-SD and NOZ cells treated with OA $(0,30,60$, and $90 \mu \mathrm{mol} / \mathrm{L})$ for 48 hours were stained with Annexin V-FITC/PI and analyzed by flow cytometry. (B) The percentage of apoptotic cells is presented as the mean \pm standard deviation. (C) Changes in apoptotic nuclear morphology were observed by Hoechst 33342 staining and visualized by fluorescent microscopy. The results shown are representative of data from three independent experiments. $* P<0.05$, $* * P<0.01, * * * P<0.001$ versus the control group.

Abbreviations: FITC, fluorescein isothiocyanate; OA, oleanolic acid; PI, propidium iodide.

A

OA concentration ( $\mu \mathrm{mol} / \mathrm{L})$

\section{Control}
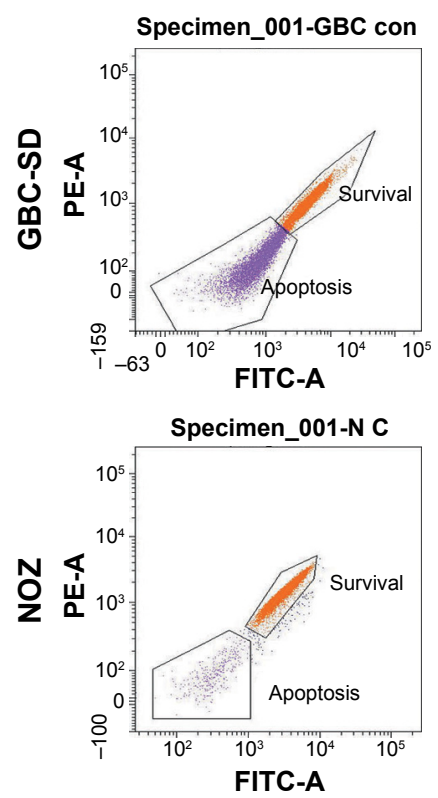

30
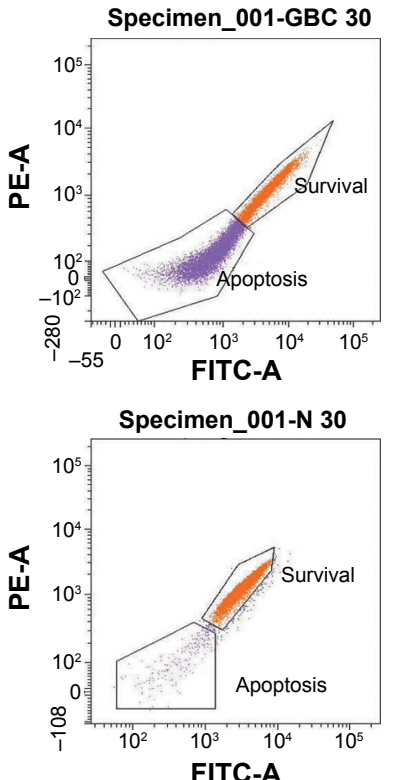

60
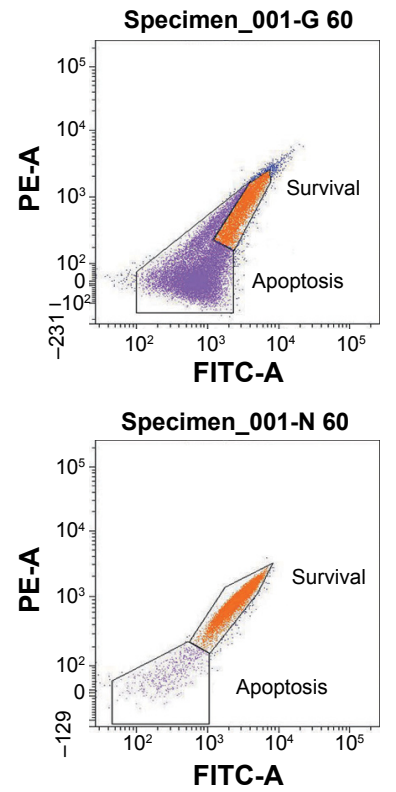

90
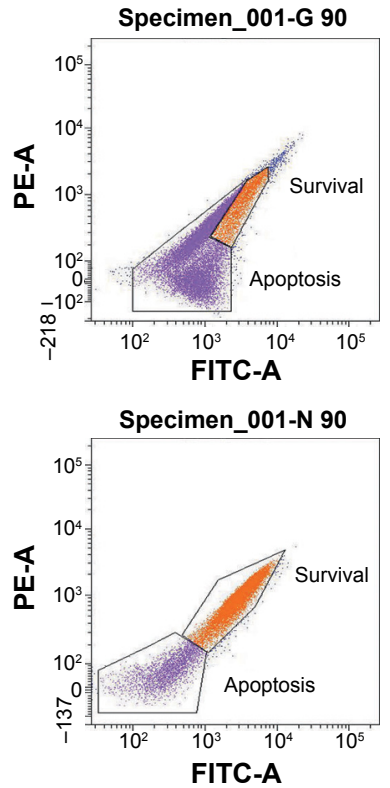

B

GBC-SD

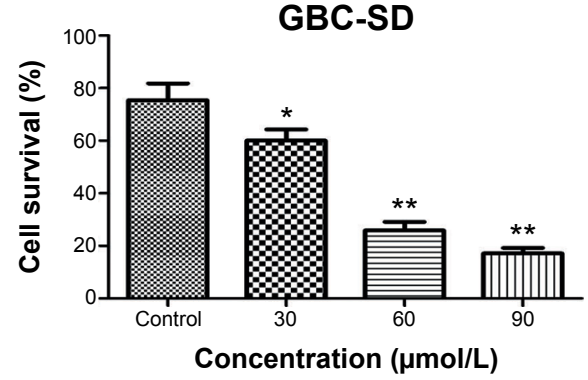

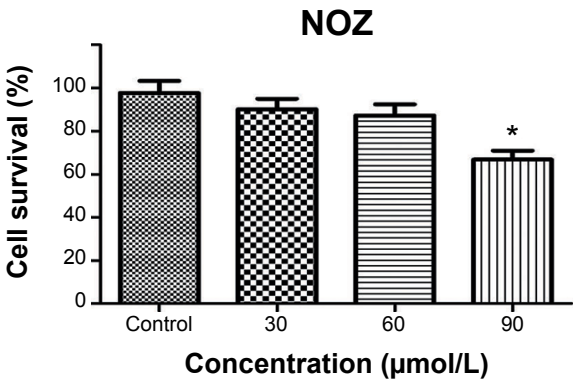

Figure 4 Oleanolic acid decreases the mitochondrial membrane potential in gallbladder cancer cells.

Notes: (A) GBC-SD and NOZ cells treated with OA (0,30,60, and $90 \mu \mathrm{mol} / \mathrm{L})$ for 48 hours were treated with Rhodamine I23, retention of which was measured by flow cytometry. (B) Corresponding histogram showing percentage cell survival, with data expressed as the mean \pm standard deviation. The results shown are representative of data from three independent experiments. ${ }^{*} P<0.05$, ${ }^{*} * P<0.0$ I versus the control group.

Abbreviations: OA, oleanolic acid; FITC, fluorescein isothiocyanate. 
A

OA concentration $(\mu \mathrm{mol} / \mathrm{L})$

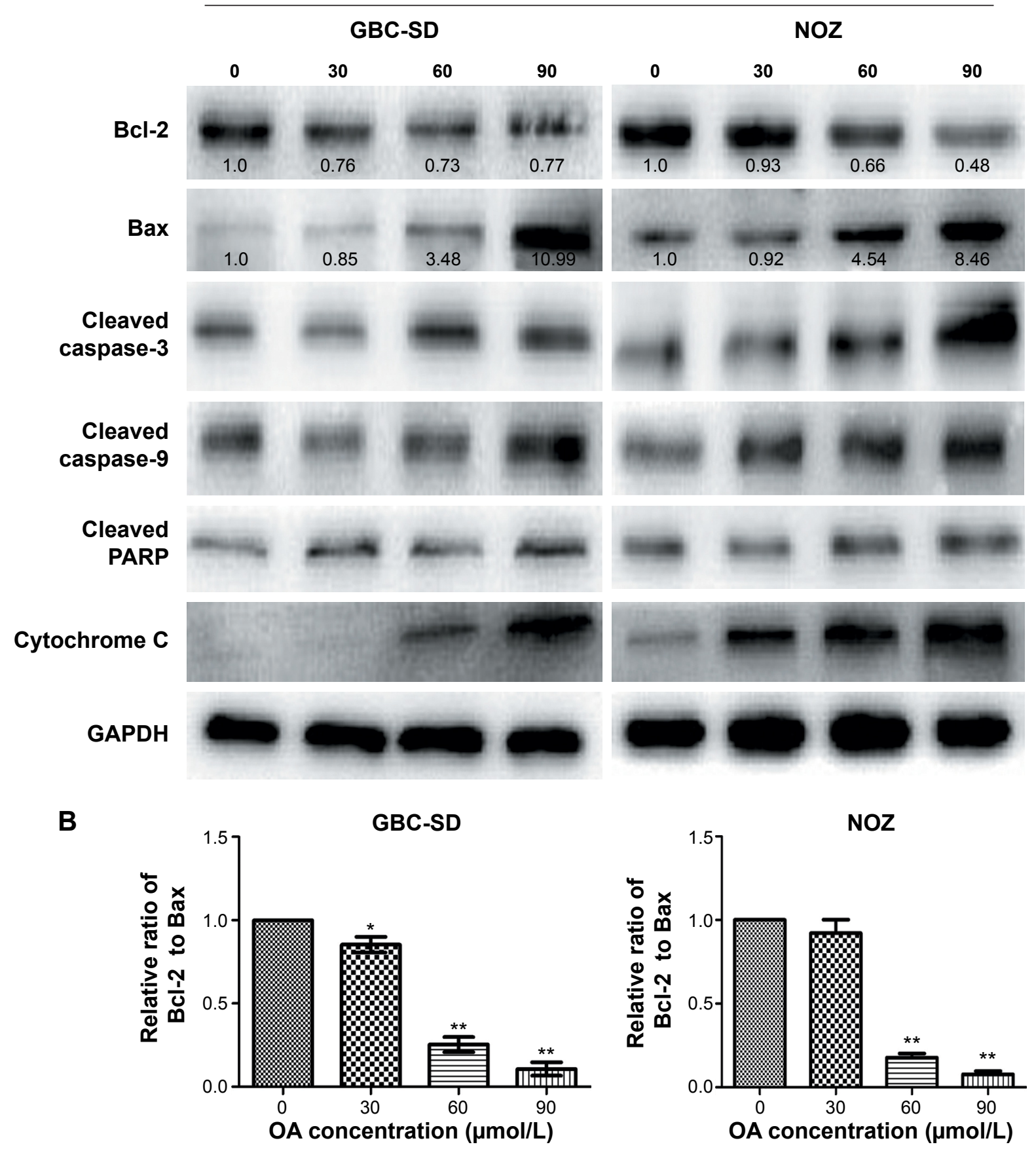

Figure 5 Oleanolic acid induced apoptosis via regulation of members of the caspase family and Bcl-2 family in gallbladder cancer cells.

Notes: (A) GBC-SD and NOZ cells were treated with OA (0, 30, 60, and $90 \mu \mathrm{mol} / \mathrm{L})$ for 48 hours. Expression levels of Bcl-2, Bax, cleaved caspase-9, cleaved caspase-3, cleaved PARP, and cytochrome $\mathrm{C}$ were detected by Western blot analysis, and GAPDH was used as a loading control. The band densities of Bcl-2 and Bax are listed under the band, and the band density of control group is designated as I.0. (B) Relative ratio of $\mathrm{Bcl}-2$ to $\mathrm{Bax}$. $* \mathrm{P}<0.05$, $* * P<0.0 \mathrm{I}$ versus the control group.

Abbreviations: GAPDH, glyceraldehyde-3-phosphate dehydrogenase; OA, oleanolic acid.

OA significantly inhibited cell cycle progression in GBC-SD and NOZ cells (Figure 6A) with a significant increase in the percentage of cells in G0/G1 phase (Figure 6B). We also evaluated levels of the cycle-related proteins cyclin D1 and CDK4 involved in G0/G1 phase by Western blot analysis, ${ }^{25}$ and a dose-dependent decrease in these two proteins was observed in GBC-SD and NOZ cells after treatment with OA for 48 hours (Figure 6C). Hence, OA exerted inhibitory effects on proliferation of GBC-SD and NOZ cells via G0/G1 phase arrest in a dose-dependent manner. 


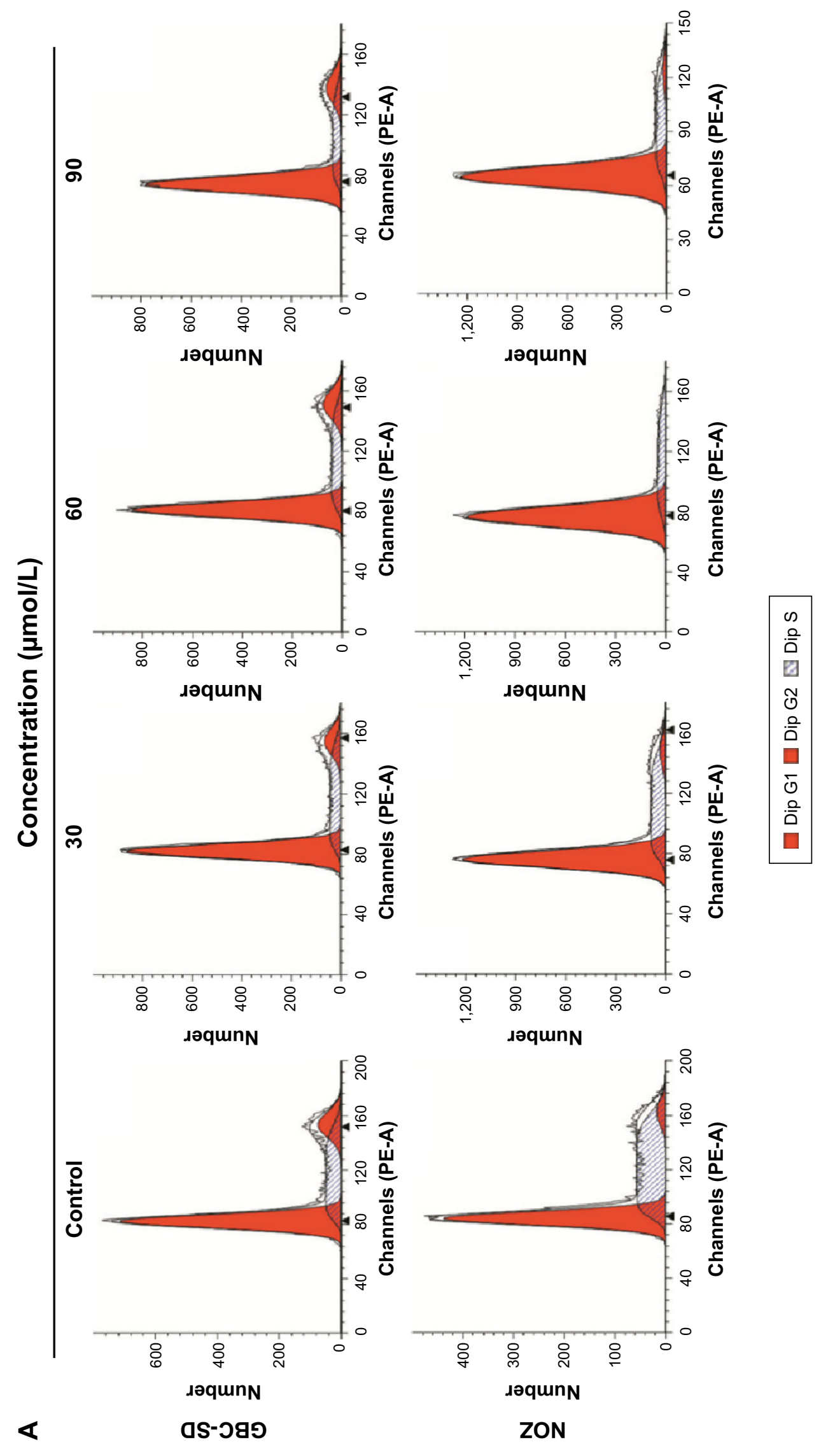



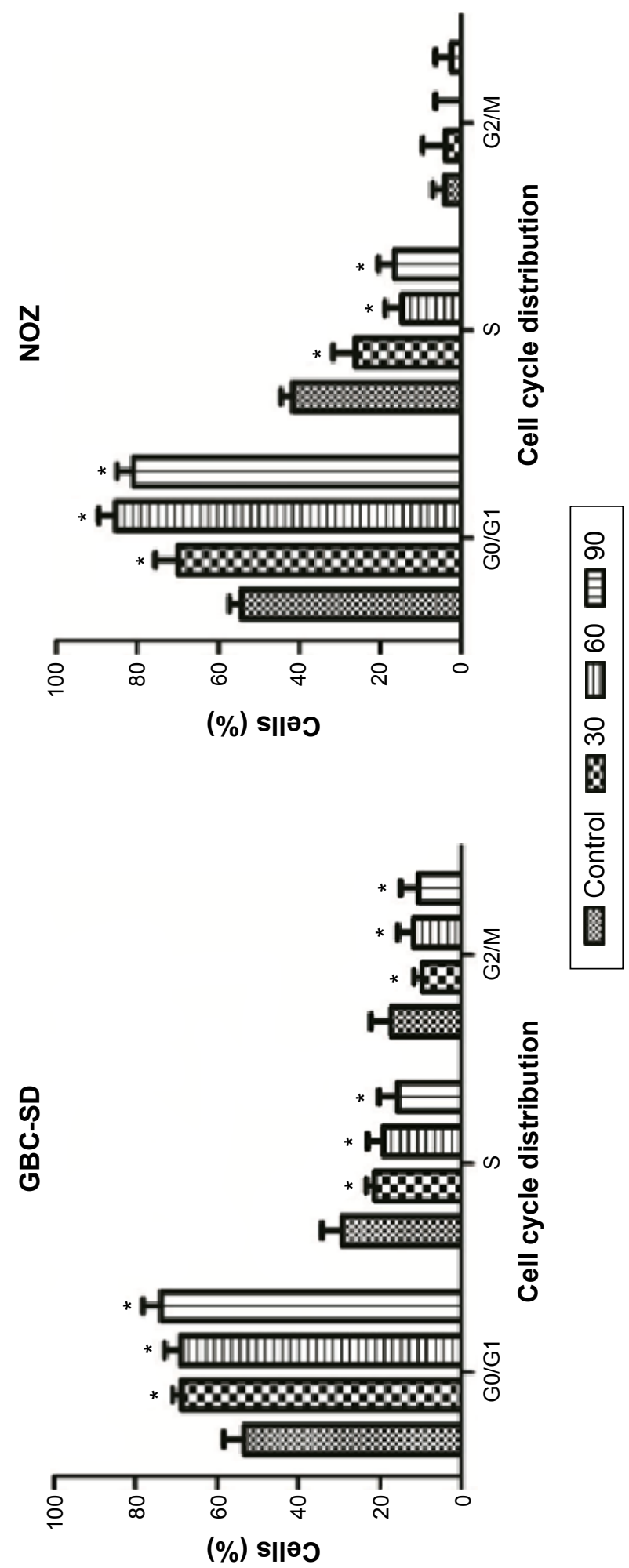

$\boldsymbol{m}$

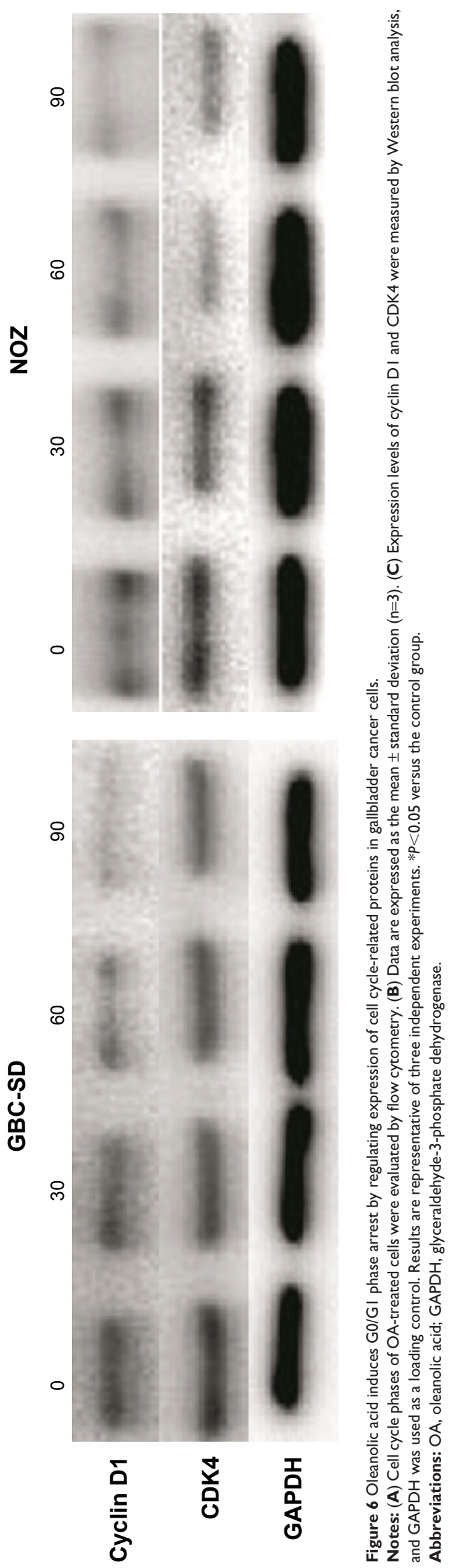




\section{OA exhibits anticancer effect in vivo}

To further determine if $\mathrm{OA}$ inhibits tumor growth in vivo and confirm its safety, vehicle (10\% DMSO and 90\% PBS) or $\mathrm{OA}(75 \mathrm{mg} / \mathrm{kg}, 150 \mathrm{mg} / \mathrm{kg})$ were injected into nude mice carrying subcutaneous NOZ tumor xenografts every 2 days for up to 15 days. ${ }^{15}$ Tumors removed from these mice are shown in Figure 7A and B, and their mean weights are shown in Figure 7C. Tumors from OA-treated mice were clearly smaller and lighter than those of mice in the vehicle group, indicating that $\mathrm{OA}$ inhibited tumor growth in mice in a dose-dependent manner. At the same time, no side effects were observed in the mice treated with OA, and all of the animals survived the experiment.

The antigen defined by the monoclonal antibody Ki-67 is a human nuclear protein, expression of which is strictly associated with cell proliferation. Ki-67 is widely used in routine pathology as a "proliferation marker" to measure the growth fraction of cells in human tumors. ${ }^{26}$ To further confirm that OA inhibits proliferation of xenograft tumors, we performed immunohistochemical staining of Ki-67. As is shown in Figure 7D and E, expression of Ki-67 in OA-treated tumors was downregulated when compared with the control group in a dose-dependent manner, indicating that OA can inhibit proliferation of gallbladder cancer cells in vivo.

\section{Discussion}

There is increased interest in the use of OA as an anticancer agent. However, the effect of OA on gallbladder carcinoma remains unknown. In this study, we found that OA could inhibit cell proliferation, induce apoptosis, and cause cell cycle arrest in human gallbladder cancer cells. An in vivo study confirmed these findings and established its safety. Therefore, OA has the potential to become a candidate for treatment of human gallbladder carcinoma.

Previous studies have shown that OA can inhibit the proliferation and growth of many cancer cell lines. ${ }^{18,27-29}$ In our study, we found that OA could inhibit cell proliferation in GBC-SD and NOZ cells. The cancer cell proliferation inhibitory effect was confirmed by MTT and colony formation assays. Since there are no normal gallbladder epithelial cell lines, we cannot compare the proliferation inhibitory ability between normal and malignant gallbladder epithelial cells. However, numerous previous studies have shown that $\mathrm{OA}$ is nontoxic, and it has been used as a hepatoprotective agent for several decades with good safety. ${ }^{30-32}$ Our in vivo study also confirmed its safety.

Next, we evaluated the apoptotic effect of OA in gallbladder cancer cells by Annexin V-FITC/PI staining with flow cytometry and Hoechst 33342 staining. Consistent with the apoptotic effects in other cancer cell lines reported in previous studies, ${ }^{18,27-29}$ our data showed that OA could induce apoptosis in GBC-SD and NOZ cells in a dose-dependent manner. The two major pathways involved in apoptosis include the mitochondria-mediated intrinsic pathway and the death receptor-induced extrinsic pathway..$^{33}$ In this study, we found out that the mitochondrial-dependent pathway played an important role in OA-mediated apoptosis by measuring the $\Delta \Psi \mathrm{m}$ and expression of the Bcl-2 family, the caspase family, cytochrome $\mathrm{C}$, and PARP with Western blot. Proteins of the Bcl-2 family are key regulators of apoptosis, exerting both proapoptotic and antiapoptotic effects. ${ }^{34}$ Increased expression of the proapoptotic protein Bax and decreased expression of the antiapoptotic protein Bcl-2 in gallbladder cancer cells were observed after administration of OA. The ratio of Bcl-2 to Bax determines the occurrence and severity of apoptosis during apoptotic stimuli. An increased ratio of Bcl-2 to Bax promotes cell survival; whereas a decreased ratio of $\mathrm{Bcl}-2$ to Bax promotes cell apoptosis. From our Western blot assay, we found that the ratio of Bcl-2 to Bax decreased sharply after adding $\mathrm{OA}$ to gallbladder cancer cells in a dose-dependent manner. Caspases are highly conserved, cysteine-dependent aspartate-specific proteases that play a central role in the initiation and execution of apoptosis. Caspase activation is generally considered to be a key marker of apoptosis, playing an important role in induction and regulation of apoptosis. ${ }^{35-37}$ PARP can be activated in cells experiencing stress and/or DNA damage, depleting adenosine triphosphate in the cell and eventually inducing apoptosis. ${ }^{38} \mathrm{In}$ the present study, expression of cleaved caspase-3, caspase-9, and PARP was significantly increased by treatment with OA for 48 hours. Cytochrome $\mathrm{c}$ is a component of the electron transport chain in the mitochondria and is involved in initiation of apoptosis. ${ }^{39}$ Treatment of gallbladder cancer cells with OA for 48 hours significantly increased the release of cytochrome $\mathrm{c}$ in a dose-dependent manner. Taken together, OA decreased cell survival by induction of apoptosis via activation of a mitochondrial-dependent pathway in human gallbladder cancer cells.

Blockade of the cell cycle is regarded as an effective strategy in the development of novel cancer therapies..$^{40}$ Previous studies have shown that OA has such an effect. ${ }^{41}$ In our study, cell cycle analysis revealed that OA induced dose-dependent G0/G1 phase arrest with an accompanying decrease of $\mathrm{S}$ and $\mathrm{G} 2 / \mathrm{M}$ phase in gallbladder cancer cells. The transition from G0 to G1 phase of the cell cycle is regulated in part by mitosis-promoting factor, which consists of cycling 

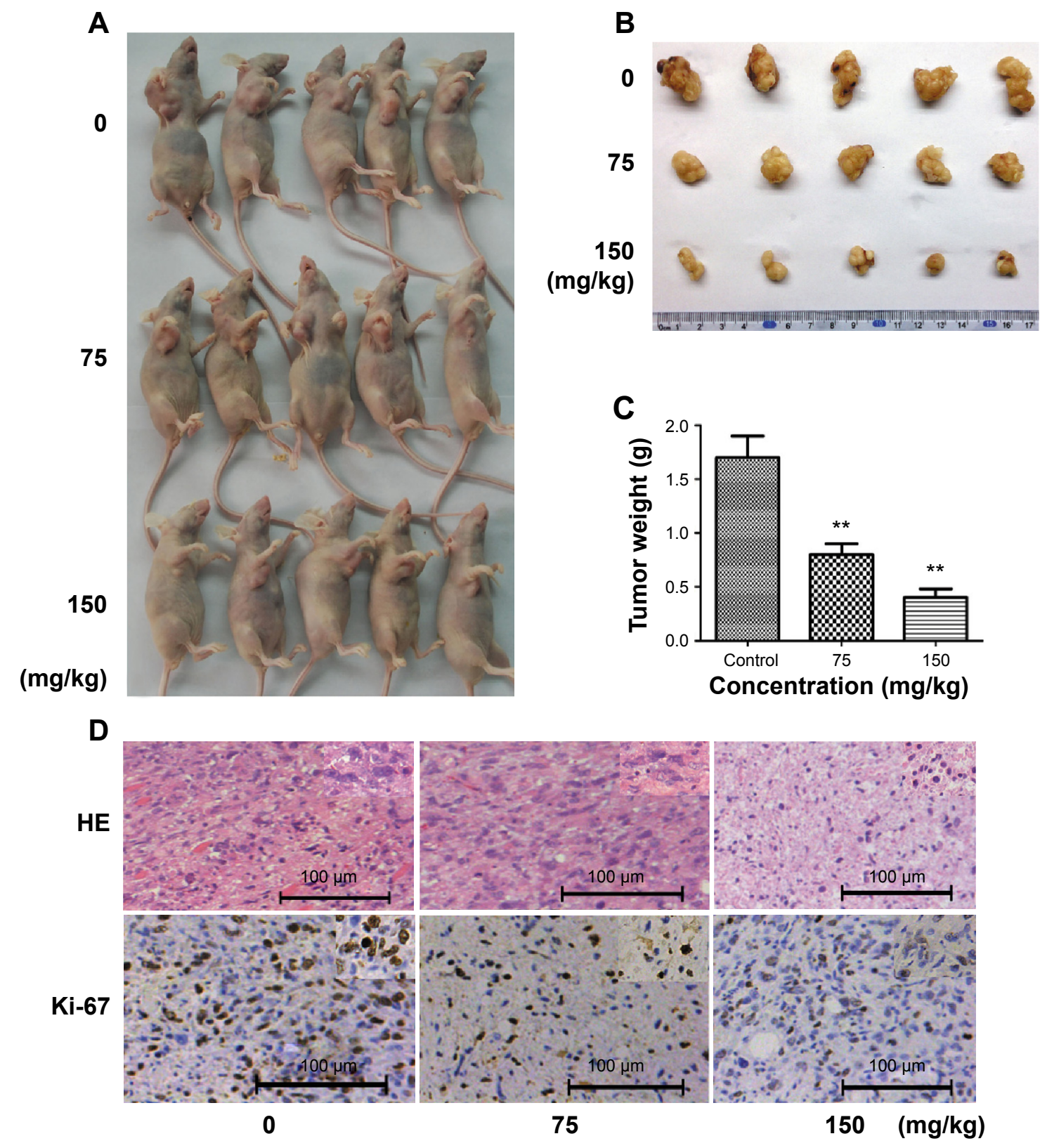

E

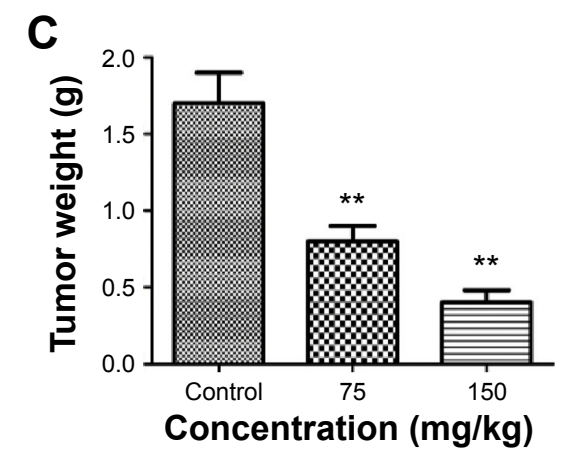

E

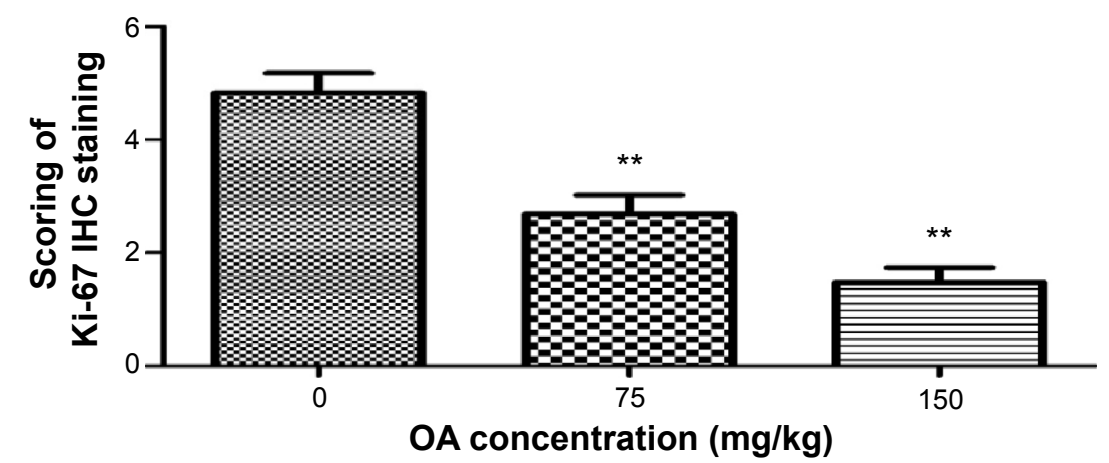

Figure 7 Oleanolic acid exhibits an anticancer effect in vivo.

Notes: (A) NOZ cells were subcutaneously injected into the right flank of nude mice. The mice were then administered $0.2 \mathrm{~mL}$ of vehicle ( $10 \%$ dimethyl sulfoxide and $90 \%$ phosphate-buffered saline) or OA $(75,150 \mathrm{mg} / \mathrm{kg}$ ) intraperitoneally every 2 days for up to 15 days. Photographs of five representative mice ( $\mathrm{n}=10$ ) from each group are presented to show the sizes of the resulting tumors. (B, C) Tumors were excised from the animals and weighed. (D) Hematoxylin-eosin staining and IHC staining of Ki-67 in xenograft tumors. (E) Scoring of $\mathrm{Ki}-67 \mathrm{IHC}$ staining. $* * \mathrm{P}<0.0 \mathrm{I}$ versus the control group.

Abbreviations: $\mathrm{OA}$, oleanolic acid; $\mathrm{HE}$, hematoxylin-eosin; $\mathrm{IHC}$, immunohistochemistry. 
D1 and CDK4. ${ }^{42}$ Increased expression of CDK4 and cyclin

D1 on Western blot further confirmed this result.

To further confirm the convincing cancer-inhibiting effect of $\mathrm{OA}$ and to test its safety, we used mice with xenograft tumors treated with OA. From the tumor volume and weight, the tumorinhibiting effect of $\mathrm{OA}$ in vivo is verified. The antigen defined by Ki-67 is a human nuclear protein, expression of which is closely associated with cell proliferation; it is widely used in routine pathology as a "proliferation marker" to measure the growth fraction of cells in human tumors. ${ }^{26}$ Our results show that expression of $\mathrm{Ki}-67$ was suppressed by OA in a dosedependent manner, meaning that OA can indeed inhibit tumor proliferation. No side effects were observed in the mice treated with OA, and all the mice were survived the experiment. In addition, $\mathrm{OA}$ is nontoxic, and has been used as a hepatoprotective agent for several decades with good safety. ${ }^{8,30-32}$

Despite the progress made in diagnosing and treating gallbladder cancer in recent years, the mortality of this lethal disease is still very high, and its morbidity is increasing year after year. ${ }^{8}$ Before new and effective biomarkers and certain risk factors are found, improving the therapeutic methods available is essential. Considering that the outcomes of radical resection, which is the only curative therapy available, is poor given the asymptomatic nature of gallbladder cancer in its early stages, and the outcomes of chemotherapy and radiotherapy are limited, ${ }^{2}$ new ways for curing this recalcitrant disease are urgently needed. Traditional Chinese medicines play an important role in many diseases, including cancer. Importantly, higher incidences of gallbladder cancer tend to be found in developing countries, including the People's Republic of China, ${ }^{2}$ patients in these countries are easy to accept treatment by Chinese medicine. Our study adequately demonstrates the inhibitory effect of OA on gallbladder cancer, and given that many patients with advanced gallbladder cancer may suffer liver dysfunction, the hepatoprotective effect of OA makes it a suitable treatment for gallbladder carcinoma.

\section{Conclusion}

Our present study provides sound evidence that OA has potent anti-gallbladder cancer cell activity that correlates with regulation of the mitochondrial-dependent apoptosis pathway and G0/G1-phase arrest. Further, OA inhibits growth of xenograft tumors in nude mice, and with no side effects. Therefore, OA has potential as a novel antitumor therapy for the treatment of gallbladder carcinoma. However, the apoptotic mechanisms involved needed to be explored in more detail.

\section{Acknowledgments}

This study was supported by the National Natural Science Foundation of China (81172026, 81272402, 81301816, 81172029), the Foundation of Shanghai Outstanding Academic Leaders (11XD1403800), the National High Technology Research and Development Program (863 Program, 2012AA022606), the Post-doctoral Research Foundation of China (2012M511107), the Foundation for Interdisciplinary Research of Shanghai Jiao Tong University (YG2011ZD07), the Shanghai Science and Technology Commission Inter-governmental International Cooperation Project (12410705900), the Shanghai Science and Technology Commission Medical-guiding Project (12401905800), and the Program for Changjiang Scholars and Postdoctoral Research Program of Shanghai (12R21415300).

\section{Disclosure}

The authors report no conflicts of interest in this work.

\section{References}

1. Cao Y, Liu X, Lu W, et al. Fibronectin promotes cell proliferation and invasion through mTOR signaling pathway activation in gallbladder cancer. Cancer Lett. 2015;360:141-150.

2. Hundal R, Shaffer EA. Gallbladder cancer: epidemiology and outcome. Clin Epidemiol. 2014;6:99-109.

3. Li M, Zhang Z, Li X, et al. Whole-exome and targeted gene sequencing of gallbladder carcinoma identifies recurrent mutations in the ErbB pathway. Nat Genet. 2014;46:872-876

4. Shu YJ, Weng H, Ye YY, et al. SPOCK1 as a potential cancer prognostic marker promotes the proliferation and metastasis of gallbladder cancer cells by activating the PI3K/AKT pathway. Mol Cancer. 2015;14:12.

5. Wang XA, Xiang SS, Li HF, et al. Cordycepin induces S phase arrest and apoptosis in human gallbladder cancer cells. Molecules. 2014;19: $11350-11365$

6. Wu XS, Wang XA, Wu WG, et al. MALAT1 promotes the proliferation and metastasis of gallbladder cancer cells by activating the ERK/ MAPK pathway. Cancer Biol Ther. 2014;15:806-814.

7. Xiang SS, Wang XA, Li HF, et al. Schisandrin B induces apoptosis and cell cycle arrest of gallbladder cancer cells. Molecules. 2014;19: $13235-13250$.

8. Groot Koerkamp B, Fong Y. Outcomes in biliary malignancy. J Surg Oncol. 2014;110:585-591.

9. Dwivedi AN, Jain S, Dixit R. Gall bladder carcinoma: Aggressive malignancy with protean loco-regional and distant spread. World J Clin Cases. 2015;3:231-244.

10. Bartlett DL, Fong Y, Fortner JG, Brennan MF, Blumgart LH. Long-term results after resection for gallbladder cancer. Implications for staging and management. Ann Surg. 1996;224:639-646.

11. Boutros C, Gary M, Baldwin K, Somasundar P. Gallbladder cancer: past, present and an uncertain future. Surg Oncol. 2012;21:e183-e191.

12. Butte JM, Matsuo K, Gonen M, et al. Gallbladder cancer: differences in presentation, surgical treatment, and survival in patients treated at centers in three countries. J Am Coll Surg. 2011;212:50-61.

13. Sharma A, Dwary AD, Mohanti BK, et al. Best supportive care compared with chemotherapy for unresectable gall bladder cancer: a randomized controlled study. J Clin Oncol. 2010;28:4581-4586.

14. Feng L, Au-Yeung W, Xu YH, Wang SS, Zhu Q, Xiang P. Oleanolic acid from Prunella Vulgaris L. induces SPC-A-1 cell line apoptosis via regulation of Bax, Bad and Bcl-2 expression. Asian Pac J Cancer Prev. 2011;12:403-408. 
15. Liu J, Zheng L, Ma L, et al. Oleanolic acid inhibits proliferation and invasiveness of Kras-transformed cells via autophagy. J Nutr Biochem. 2014;25:1154-1160.

16. Pratheeshkumar P, Kuttan G. Oleanolic acid induces apoptosis by modulating $\mathrm{p} 53$, Bax, $\mathrm{Bcl}-2$ and caspase-3 gene expression and regulates the activation of transcription factors and cytokine profile in $\mathrm{B} 16 \mathrm{~F}$. J Environ Pathol Toxicol Oncol. 2011;30:21-31.

17. Wang $X$, Bai $H$, Zhang $X$, et al. Inhibitory effect of oleanolic acid on hepatocellular carcinoma via ERK-p53-mediated cell cycle arrest and mitochondrial-dependent apoptosis. Carcinogenesis. 2013;34: 1323-1330.

18. Wei J, Liu M, Liu H, et al. Oleanolic acid arrests cell cycle and induces apoptosis via ROS-mediated mitochondrial depolarization and lysosomal membrane permeabilization in human pancreatic cancer cells. $J$ Appl Toxicol. 2013;33:756-765.

19. Zhao X, Liu M, Li D. Oleanolic acid suppresses the proliferation of lung carcinoma cells by miR-122/cyclin G1/MEF2D axis. Mol Cell Biochem. 2015;400:1-7.

20. Saris NE, Teplova VV, Odinokova IV, Azarashvily TS. Interference of calmidazolium with measurement of mitochondrial membrane potential using the tetraphenylphosphonium electrode or the fluorescent probe rhodamine 123. Anal Biochem. 2004;328:109-112.

21. Rodriguez-Vargas JM, Ruiz-Magana MJ, Ruiz-Ruiz C, et al. ROSinduced DNA damage and PARP-1 are required for optimal induction of starvation-induced autophagy. Cell Res. 2012;22:1181-1198.

22. She EX, Hao Z. A novel piperazine derivative potently induces caspasedependent apoptosis of cancer cells via inhibition of multiple cancer signaling pathways. Am J Transl Res. 2013;5:622-633.

23. Zhao X, Ma S, Liu N, Liu J, Wang W. A polysaccharide from Trametes robiniophila Murrill induces apoptosis through intrinsic mitochondrial pathway in human osteosarcoma (U-2 OS) cells. Tumour Biol. February 11, 2015. [Epub ahead of print].

24. Walensky LD. BCL-2 in the crosshairs: tipping the balance of life and death. Cell Death Differ. 2006;13:1339-1350.

25. Nigg EA. Cyclin-dependent protein kinases: key regulators of the eukaryotic cell cycle. Bioessays. 1995;17:471-480.

26. Schluter C, Duchrow M, Wohlenberg C, et al. The cell proliferationassociated antigen of antibody Ki-67: a very large, ubiquitous nuclear protein with numerous repeated elements, representing a new kind of cell cycle-maintaining proteins. J Cell Biol. 1993;123:513-522.

27. Liu J, Wu N, Ma LN, et al. p38 MAPK signaling mediates mitochondrial apoptosis in cancer cells induced by oleanolic acid. Asian Pac J Cancer Prev. 2014;15:4519-4525.
28. Lu Y, Zhu M, Chen W, Yin L, Zhu J, Chen N. Oleanolic acid induces apoptosis of MKN28 cells via AKT and JNK signaling pathways. Pharm Biol. 2014;52:789-795.

29. Ma W, Wang DD, Li L, et al. Caveolin-1 plays a key role in the oleanolic acid-induced apoptosis of HL-60 cells. Oncol Rep. 2014;32:293-301.

30. Joy Hoskeri H, Krishna V, Vinay Kumar B, Shridar AH, Ramesh Babu K, Sudarshana MS. In vivo prophylactic effects of oleanolic acid isolated from chloroform extract of Flaveria trinervia against ethanol induced liver toxicity in rats. Arch Pharm Res. 2012;35:1803-1810.

31. Liu J, Wu Q, Lu YF, Pi J. New insights into generalized hepatoprotective effects of oleanolic acid: key roles of metallothionein and Nrf2 induction. Biochem Pharmacol. 2008;76:922-928.

32. Reisman SA, Aleksunes LM, Klaassen CD. Oleanolic acid activates Nrf2 and protects from acetaminophen hepatotoxicity via Nrf2-dependent and Nrf2-independent processes. Biochem Pharmacol. 2009;77: 1273-1282.

33. Spencer SL, Sorger PK. Measuring and modeling apoptosis in single cells. Cell. 2011;144:926-939.

34. Hardwick JM, Soane L. Multiple functions of BCL-2 family proteins. Cold Spring Harb Perspect Biol. 2013;5(2):a008722.

35. McIlwain DR, Berger T, Mak TW. Caspase functions in cell death and disease. Cold Spring Harb Perspect Biol. 2013;5:a008656.

36. Parrish AB, Freel CD, Kornbluth S. Cellular mechanisms controlling caspase activation and function. Cold Spring Harb Perspect Biol. 2013;5(6):a008672.

37. Poreba M, Strozyk A, Salvesen GS, Drag M. Caspase substrates and inhibitors. Cold Spring Harb Perspect Biol. 2013;5:a008680.

38. Aredia F, Scovassi AI. Poly(ADP-ribose): a signaling molecule in different paradigms of cell death. Biochem Pharmacol. 2014;92:157-163.

39. Li P, Nijhawan D, Budihardjo I, et al. Cytochrome c and dATPdependent formation of Apaf-1/caspase-9 complex initiates an apoptotic protease cascade. Cell. 1997;91:479-489.

40. Buolamwini JK. Cell cycle molecular targets in novel anticancer drug discovery. Curr Pharm Des. 2000;6:379-392.

41. Zhou R, Zhang Z, Zhao L, et al. Inhibition of mTOR signaling by oleanolic acid contributes to its anti-tumor activity in osteosarcoma cells. J Orthop Res. 2011;29:846-852.

42. Malumbres M, Barbacid M. Cell cycle, CDKs and cancer: a changing paradigm. Nat Rev Cancer. 2009;9:153-166.
Drug Design, Development and Therapy

\section{Publish your work in this journal}

Drug Design, Development and Therapy is an international, peerreviewed open-access journal that spans the spectrum of drug design and development through to clinical applications. Clinical outcomes, patient safety, and programs for the development and effective, safe, and sustained use of medicines are a feature of the journal, which

\section{Dovepress}

has also been accepted for indexing on PubMed Central. The manuscript management system is completely online and includes a very quick and fair peer-review system, which is all easy to use. Visit http://www.dovepress.com/testimonials.php to read real quotes from published authors. 